\title{
Etnobotani Tanaman Kelor (Moringa oleifera Lam.) di Desa Kedungbulus Gembong Pati
}

\author{
Brintan Yonaka Dhea Dani ${ }^{1}$, Baiq Farhatul Wahidah ${ }^{2}$, Andang Syaifudin ${ }^{2}$ \\ ${ }^{1}$ Program Studi Pendidikan Biologi, Fakultas Sains dan Teknologi, UIN Walisongo Semarang \\ ${ }^{2}$ Program Studi Biologi Fakultas Sains dan Teknologi, UIN Walisongo Semarang \\ Jl. Prof Dr. Hamka (Kampus II), Ngaliyan, Semarang, Jawa Tengah 50185 \\ ${ }^{1}$ Email: yddbrintan@gmail.com, ${ }^{2}$ Email: andang.syaifudin@walisongo.ac.id
}

\begin{abstract}
The potential of Moringa tree related to health properties is still not fully utilized by the people in Pati. Mrs. Muryati, a resident of Kedungbulus Village, Gembong Subdistrict, Pati, was one of the residents who was moved to campaign for the use of Moringa leaves. The purpose of this study was to determine public perceptions about the potential of Moringa plants in the village of Kedungbulus Gembong Pati. This research uses survey methods which include: literature study, field observations, interviews using questionnaires, semistructure interview techniques and using random sampling techniques and purposive sampling. Random sampling sampling from the community taken randomly, while purposive sampling sampling from community leaders such as informants of production houses, village heads, shamans etc. The results obtained from the relationship between community and Moringa plants are explained from interviews with the public perception of Moringa plants.
\end{abstract}

Keywords:Ethnobotany, Kedungbulus, kelor, Moringa

\section{Pendahuluan}

Etnobotani secara terminologi merupakan hubungan atau interaksi antara tumbuhan tertentu dengan kelompok masyarakat (Etnis). Etnobotani menjelaskan tentang pengetahuan masyarakat tradisional terhadap penggunaan tumbuhan dalam menunjang kehidupannya seperti untuk kepentingan makan, pengobatan, bahan bangunan, upacara adat, budaya, bahan pewarna dan sebagainya. Kelompok masyarakat sesuai dengan karakteristik wilayah dan adat masing-masing memiliki ketergantungan terhadap tumbuhan, paling tidak untuk sumber bahan pangan (Suryadarma, 2008).

Desa Kedungbulus merupakan desa kecil di Kecamatan Gembong, Kabupaten Pati Provinsi Jawa Tengah yang letaknya di lereng Gunung Muria $9 \mathrm{~km}$ ke arah barat dari pusat kota Pati . Desa Kedungbulus merupakan desa terkecil kedua setelah Desa Wonosekar di antara 11 Desa di Kecamatan Gembong dan terbagi menjadi 4 padukuhan, 12 RT dan 3 RW. Desa Ini merupakan salah satu desa paling maju di Kecamatan Gembong bahkan di Kabupaten Pati. Adapun jumlah Penduduk yang relatif sedikit dibandingkan dengan desa-desa yang lain di Kecamatan Gembong, yang kurang dari 3.000 jiwa. Potensi Pohon Kelor masih belum dimanfaatkan maksimal oleh masyarakat di Desa Kedungbulus, Kecamatan Gembong, Pati. Tumbuhan kelor hanya sebatas dijadikan makanan ternak oleh warga, adanya kampanye pemanfaatan daun kelor oleh salah satu warga kini sudah 70 persen warga di Desa Kedungbulus, Kecamatan Gembong, Pati menanam pohoh kelor. Selama beberapa tahun mengkampanyekan pohon kelor, sudah membuahkan hasil dan kini warga mulai memanfaatkan sebagai obat kesehatan dan makanan.

Moringa oleifera Lam. yang lebih dikenal dengan nama kelor di Indonesia, diperkenalkan dari India pada saat zaman penjajahan dan 
memberikan pengaruh yang cukup kuat dengan masuknya agama Hindu dan Budha di Indonesia hingga akhirnya masyarakat turut menanam tanaman kelor. Selain Indonesia, tanaman ini juga menyebar ke seluruh daerah Asia Selatan, di beberapa negara Asia Tenggara, Semenanjung Arab, tropis Afrika, Amerika Tengah, Karibia, dan tropis Amerika Selatan.Hasil dari tanaman kelor di Indonesia pada saat itu memberikan efek positif terhadap berbagai penyakit yang pada umumnya dilakukan dengan melakukan ritual pengusiran roh jahat/ilmu hitam. Karena pada saat itu masyarakat masih percaya dengan hal-hal mistis, hingga saat ini kelor kerap kali dikenal sebagai tanaman mistis. Mitos-mitos yang beredar pun cukup banyak, yaitu sebagai tolak bala untuk rumah yang baru dibangun, pengusir makhluk halus, dan melunturkan kekuatan magis dari susuk (Kurniasih, 2015).

Disamping mitos yang beredar tersebut, kelor hingga saat ini telah menyumbangkan perannya sebagai tanaman obat dalam dunia medis berkat kandungan nutrisi yang dimilikinya. Berdasarkan hasil penelitian sorang peneliti bernama Fuglie LJ dalam bukunya yang berjudul The Miracle Tree: The Multiple Attributes of Moringa, daun kelor memiliki kandungan vitamin A, vitamin C, vitamin B, kalsium, zat besi, dan protein dalam jumlah yang sangat tinggi namun masih mudah untuk dicerna dan diasimilasi oleh tubuh manusia. Tak hanya itu, daun kelor juga mengandung lebih dari 40 antioksidan dan beragam mineral penting yang merupakan sumber protein yang baik. Berkat dari kandungannya itu kelor diberi nama "Miracle Tree" atau "Tree of Life". Secara internasional tanaman ini telah dipromosikan oleh berbagai organisasi seperti WHO (World Health Organization), National Geographic, National Institute of Health, dan lainlain untuk mengatasi malnutrisi di negara-negara miskin (Krisnadi, 2015).

Tanaman kelor dapat dimanfaatkan secara keseluruhan dari bagian akar, daun, buah, bunga dan bijinya. Bunga dapat digunakan sebagai tonik, diuretik, sakit radang sendi, dan obat cuci mata, tunas kelor digunakan untuk obat liver, ginjal, dan sakit pada sendi, akar digunakan untuk sakit kembung dan demam. Akar dilarutkan dan dioleskan pada kulit untuk mengatasi iritasi kulit. Biji digunakan untuk demam, rematik, dan sakit kulit. Daunnya dapat digunakan sebagai antioksidan (Fuglie, 1999).

\section{Metode}

Penelitian ini dilaksanakan di desa Kedungbulus Gembong Pati pada tanggal 24 April 2019-2 Mei 2019. Teknik pengumpulan data didapatkan dari pengetahuan asli masyarakat tentang potensi mengenai tanaman kelor dengan melakukan wawancara secara semistruktur (semistructure interview) dengan responden menggunakan panduan kuesioner dengan melakukan wawancara dengan responden kunci (key person) yaitu pada tokoh-tokoh masyarakat dan masyarakat yang memiliki tanaman kelor sekaligus memanfaatkannya, atau masyarakat yang tidak memiliki tanaman kelor tapi masih memanfaatkannya. Pengambilan sampel responden sebanyak 32 responden untuk mewakili semua masyarakat yang ada di desa Kedungbulus Gembong Pati.

Penelitian dilapangan untuk mendapatkan karakteristik tanaman kelor serta pengetahuan mengenai etnobotani masyarakat desa Kedungbulus menggunakan teknik simple random sampling dan purposive sampling. Purposive sampling yakni pengambilan sampel dengan cara menetapkan ciri-ciri khusus yang sesuai dengan tujuan penelitian sehingga diharapkan data yang diperoleh nantinya bisa lebih representative. Sedangkan Random sampling adalah teknik pengambilan sampel dari anggota populasi yang dilakukan secara acak tanpa memperhatikan strata yang ada dalam populasi itu (Sugiyono,2015).

Fokus dalam penelitian ini adalah etnobotani tanaman kelor didaerah Kedungbulus Gembong Pati mulai dari pengetahuan masyarakat 
tentang tanaman kelor, nutrisi hingga pemanfaatannya.

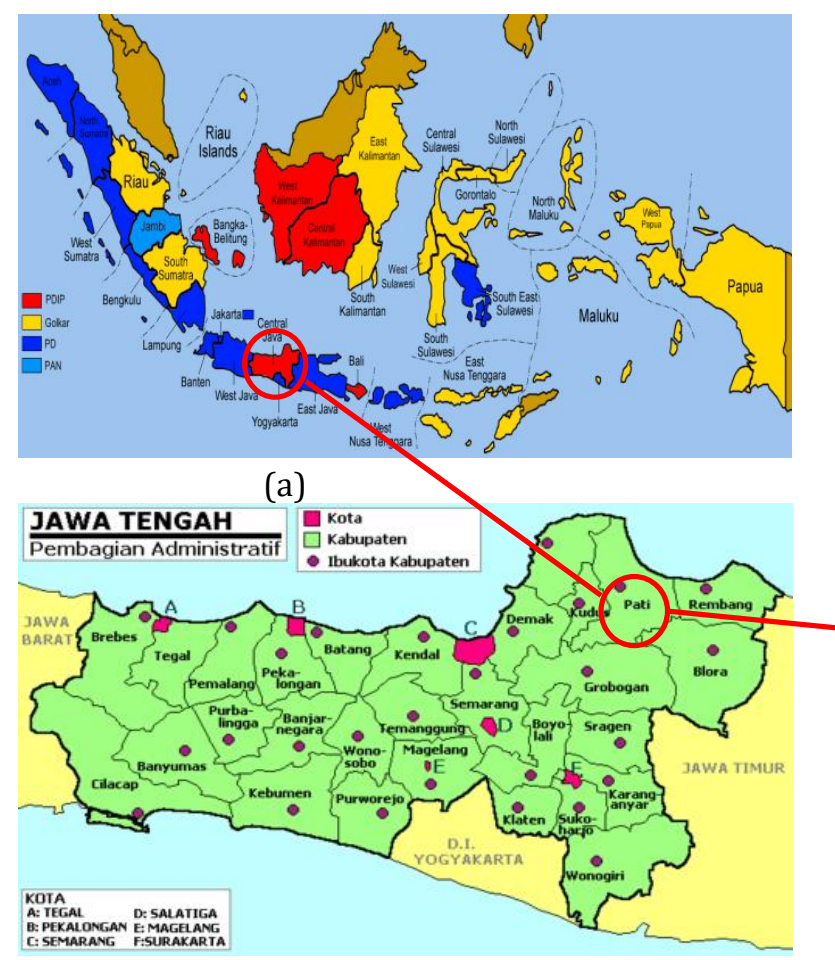

(b)
Penelitian dilaksanakan di desa Kedungbulus Gembong Pati, berikut ini adalah peta lokasi penelitian :

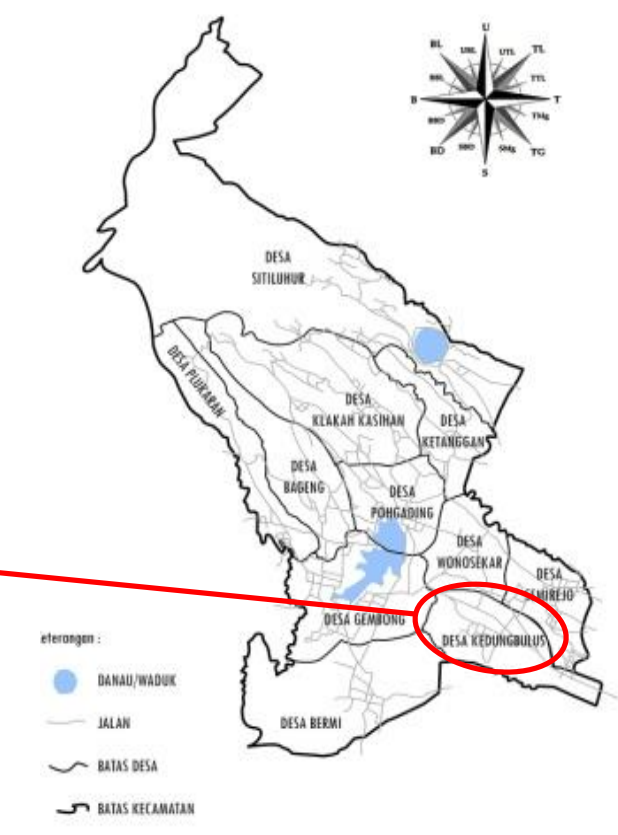

(c)

Gambar 1. Peta a.Jawa Tengah, b. Kabupaten Pati, c. Desa Kedungbulus Sumber : (mapsoftworld.com, 2015)

\section{Hasil dan Pembahasan}

Mahakarya Mulya didirikan pada tahun 1999 oleh Ibu Muryati dan Bapak Rusmani, dengan bertekat ingin mandiri tidak ingin terikat dengan manapun maka dari itu memiliki ide usaha sendiri yang sekarang memiliki outlet di Pasar Pragola Pati dengan tujuan ingin memberdayakan masyarakat serta menambah wawasan dan relasi. Masyarakat desa Kedungbulus sebelum adanya kampanye tanaman kelor oleh Ibu Muryati, masih menganggap tanaman kelor sebagai tanaman yang mistis dan tidak bermanfaat, masih digunakan untuk ritual tertentu dan makanan ternak. Dari tahun ke tahun, masyarakat telah paham begitu banyak manfaat dari tanaman kelor, hingga setiap pekarangan rumah ditanami tanaman kelor dan dimanfaatkan sebagai tanaman obat tradisional oleh masyarakat. Tidak dapat dipungkiri bahwasanya tidak dapat sepenuhnya menghilangkan mitos dari nenek moyang, masih ada kepercayaan untuk ritual tertentu dengan menggunakan tanaman kelor.

Hasil yang didapatkan dari wawancara yaitu masyarakat desa Kedungbulus dan tanaman kelor saling berhubungan. Pemanfaatan tanaman kelor didesa Kedungbulus terbagi dalam beberapa potensi antara lain pengobatan, pangan, pagar, pembibitex) dan ritual adat. Pemanfaatan tanaman kelor paling banyak adalah digunakan sebagai pangan sekaligus dari hasil pangan atau produk tersebut dapat sebagai pengobatan tradisional. 


\section{Potensi Tanaman Kelor}

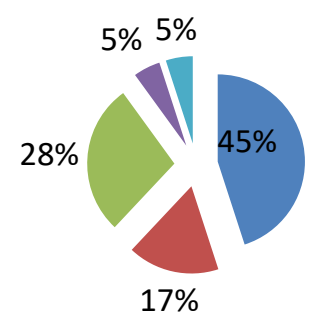

Gambar 2 : Grafik Potensi Tanaman Kelor

Tanaman kelor yang berpotensi sebagai obat tradisional di desa Kedungbulus Gembong Pati ditemukan sebagai obat darah timggi, kolesterol, asam urat, kanker, kencing manis, segala penyakit lambung. Di India, kandungan nutrisi yang ada pada tanaman kelor mampu mengobati 300 jenis penyakit, salah satu diantaranya seperti yang telah ditemukan di desa Kedungbulus Gembong Pati (Krisnadi, 2015). Sementara itu pemanfaatan tanaman kelor untuk ritual adat istiadat di desa Kedungbulus Gembong Pati, diantaranya digunakan untuk penghilang santet, pengasihan, pemandian mayat, pengusir roh jahat, santet. Ritual adat di desa Kedungbulus sudah mulai berkurang dari zaman ke zaman, seiring bergilirnya zaman ke modern adat istiadat semakin menghilang, tetapi tidak semua warisan nenek moyang hilang secara langsung. Beberapa masih ada yang percaya dengan mitos tanaman kelor, dari hasil wawancara warga mengatakan bawah menanam tanaman kelor dipagar rumah dapat menghindarkan dari roh-roh jahat yang masuk kerumah, ketika ada orang yang sakit tetapi tak kunjung sembuh dan tidak mengetahui penyakitnya digepyok (dipukul) daun kelor dapat meninggal dengan tenang, dapat memberi pengasihan, yang dimaksud adalah keinginan seseorang seperti ingin mendapatkan jodoh, mendapatkan pekerjaan, disegani teman-teman dll.

Tanaman kelor yang berpotensi sebagai pangan di desa Kedungbulus ditemukan sebagai olahan makanan seperti sayur, lalapan, ongseng bacem, ongseng polong, teh kelor, keripik dan mie. Dalam rumah produksi "Mahakarya Mulya" tanaman kelor diolah menjadi teh celup, teh serbuk, teh daun kering, kopi kelor, keripik kelor, emping, minyak oles, mie, sosis, eskrim, cendol, gethuk, roti kering, pudding, telur kelor.

Tanaman kelor dimanfaatkan oleh masyarakat desa Kedungbulus mulai dari batang, daun, polong, biji. Bagian yang paling banyak digunakan adalah daun, responden menggunakan daun untuk pengobatan, pangan, dan ritual adat. Sedangkan batang digunakan untuk pembibitan dan kayu bakar. Untuk polong, akar dan bunga tidak terlalu intensif digunakan oleh masyarakat desa Kedungbulus karena tidak selalu tumbuh, tanaman kelor tumbuh subur hanya dibagian daunnya saja.

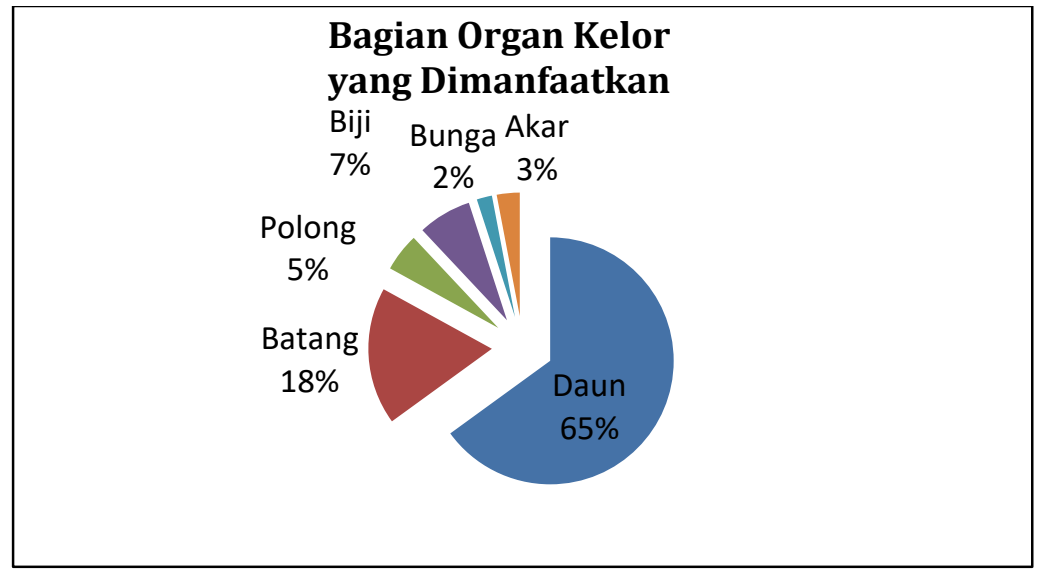

Gambar 4 : Grafik Presentase bagian organ kelor yang dimanfaatkan 
Berdasarkan hasil wawancara dengan responden di desa Kudungbulus Gembong Pati, didapatkan data hasil sumber pengetahuan responden yang memanfaatkan tanaman kelor. Gambar 3 tersebut menunjukkan bahwa masyarakat desa Kedungbulus memperoleh informasi dari nenek moyang mereka sebanyak
$30 \%$ mengenai ritual adat, pengobatan, dari rumah produksi mahakarya mulya sebanyak $45 \%$, awal mengkampanyekan tanaman kelor ke masyarakat bahwa kelor memiliki banyak nutrisi yakni dari rumah produksi tersebut, dan dukun sebanyak $25 \%$.

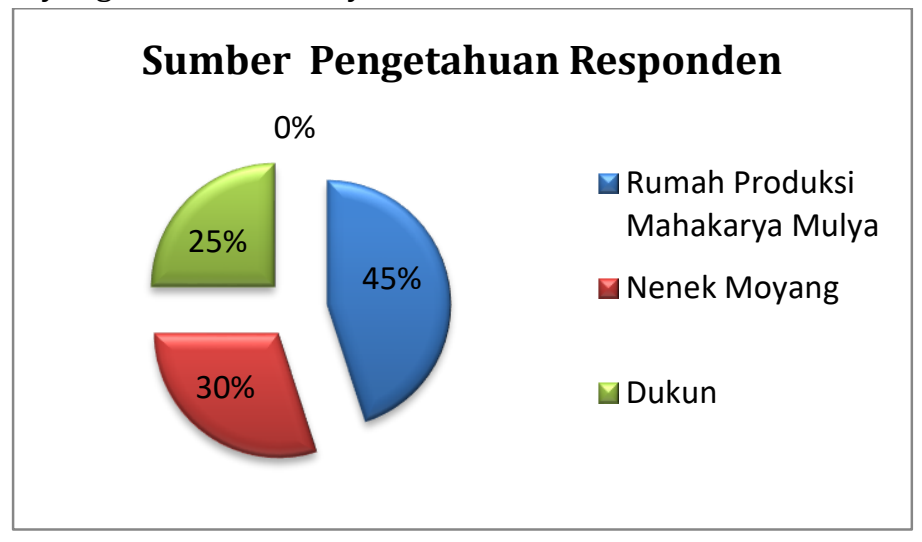

Grafik 5 : Grafik Presentase Sumber Pengetahuan Responden

Berdasarkan hasil observasi dilapangan hamper seluruh masyarakat menanam tanaman kelor dipagar rumahnya, banyaknya nutrisi yang terkandung dalam tanaman kelor menyebabkan masyarakat menanam kelor sebagai pangan hingga sebagai obat tradisional. Berikut tabel khasiat dan morfologi tanaman kelor (Tabel 1) serta produk hasil olahannya oleh Ibu Muryati informan rumah produksi "Mahakarya Mulya" (Tabel 2).

Tabel 1. Morfologi dan Nutrisi Tanaman Kelor

\begin{tabular}{lll}
\hline \multicolumn{1}{c}{ Bagian Tanaman } & \multicolumn{1}{c}{ Khasiat Penyembuhan } & \multicolumn{1}{c}{ Referensi } \\
\hline Akar & $\begin{array}{l}\text { Antilithic, rubefacient, vesicant, The Wealth of India, } \\
\text { karminatif, antifertilitas, anti-inflamasi, 1962; Padmarao } \text { et al., } \\
\text { stimulan bagi penderita lumpuh, 1996;Dahot, 1988; } \\
\text { bertindak sebagai acardiac / tonik Ruckmani } \text { et al., 1998 } \\
\text { peredaran darah, digunakan sebagai } \\
\text { pencahar, aborsi, mengobati rematik, } \\
\text { radang, sakit artikular, nyeri punggung } \\
\text { bawah atau ginjal dan sembelit. }\end{array}$ \\
\end{tabular}



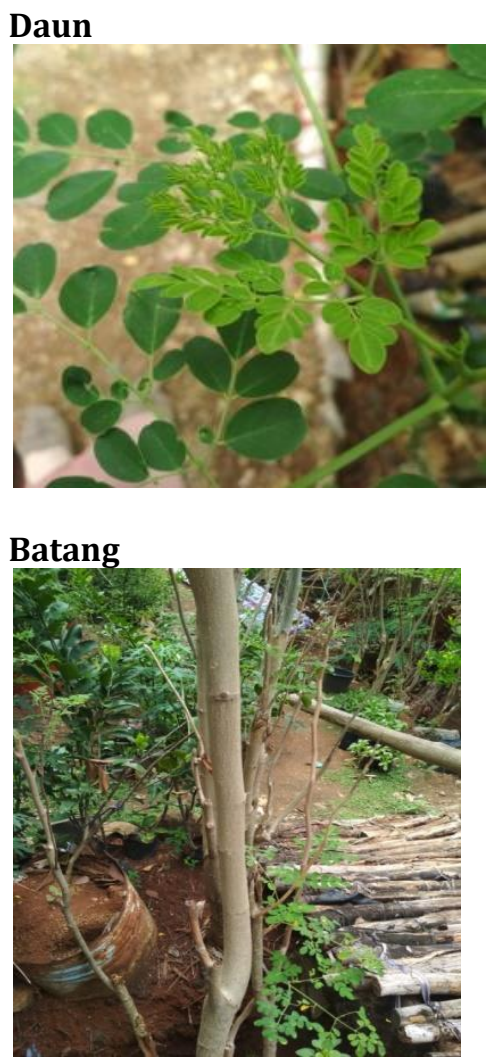

Polong/Buah

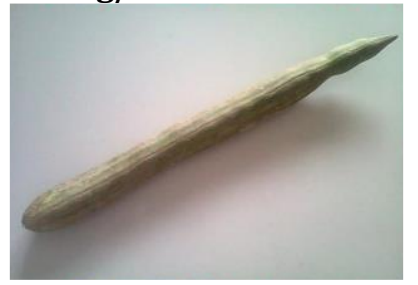

\section{Bunga}

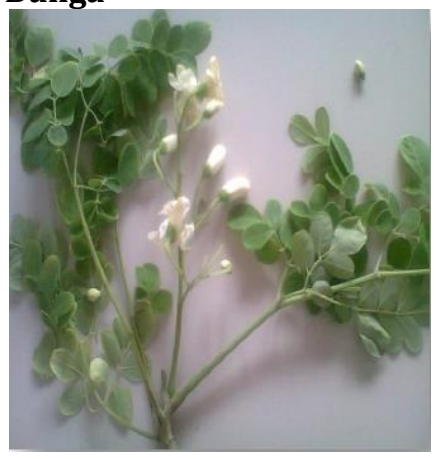

Pencahar, diterapkan sebagai tapal untuk luka, dioleskan pada pelipis untuk sakit kepala, digunakan untuk demam, sakit tenggorokan, bronkitis, infeksi telinga dan mata, kudis dan penyakit selesema, jus daun diyakini untuk mengontrol kadar glukosa, diterapkan untuk mengurangi bengkak pada kelenjar.

Rubefacient, vesicant dan digunakan untuk menyembuhkan penyakit mata dan untuk pengobatan pasien mengigau, mencegah pembesaran limpa dan pembentukan kelenjar. TB leher, untuk menghancurkan tumor dan untuk menyembuhkan bisul. Jus dari kulit batang yang dimasukkan ke dalam telinga untuk meredakan sakit telinga dan juga ditempatkan di rongga gigi sebagai penghilang rasa sakit, dan memiliki aktivitas anti-TBC

Digunakan untuk karies gigi, astringent dan rubefacient Diolah ongseng digunakan untuk meredakan sakit kepala, demam, keluhan usus, disentri, asma dan untuk mengobati sifilis dan rematik.

Memiliki nilai khasiat obat tinggi sebagai stimulan, afrodisiak, aborsi, cholagogue, digunakan untuk menyembuhkan radang, penyakit otot, histeria, tumor, dan pembesaran limpa, menurunkan kolesterol fosfolipid, serum, trigliserida, VLDL kolesterol, LDL rasio fosfolipid dan indeks aterogenik, penurunan profil lipid hati, jantung dan aorta pada kelinci hiperkolesterol dan meningkat ekskresi kolesterol.
Morton, 1991; Fuglie, 2001; Makonnen et al., 1997; The Wealth of India, 1962; Dahot, 1988

Bhatnagar et al., 1961; Siddhuraju and Becker, 2003

Fuglie, 2001

Nair and Subramanian, 1962; Bhattacharya et al., 1982; Dahot, 1998; Siddhuraju and Becker, 2003; Mehta et al., 2003 


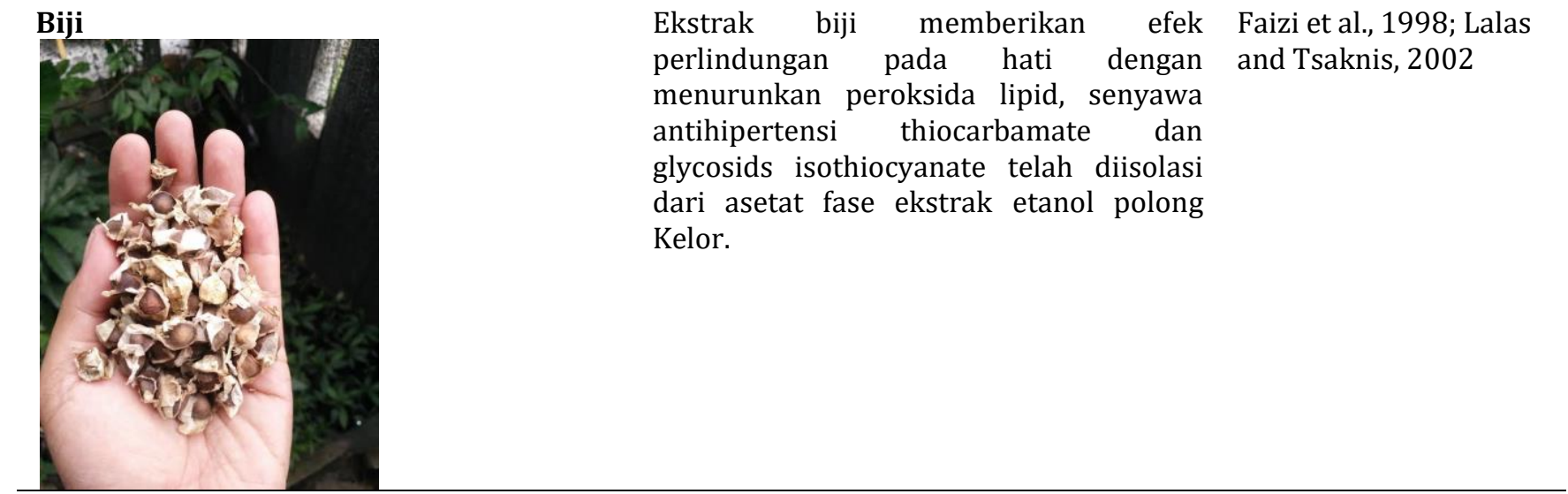

Sumber : (Sajid, 2006)

Tabel 2. Produk Olahan Tanaman Kelor

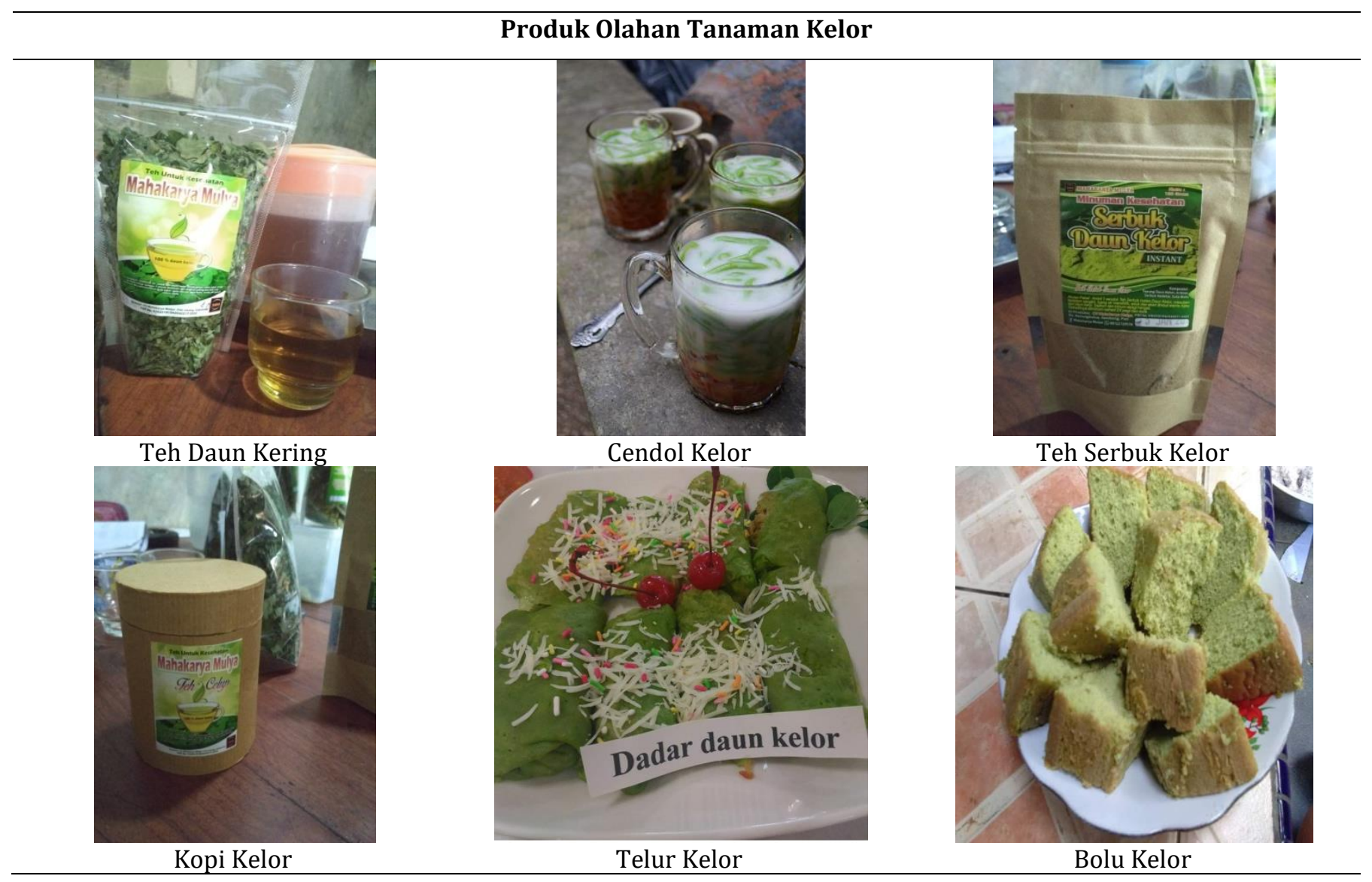




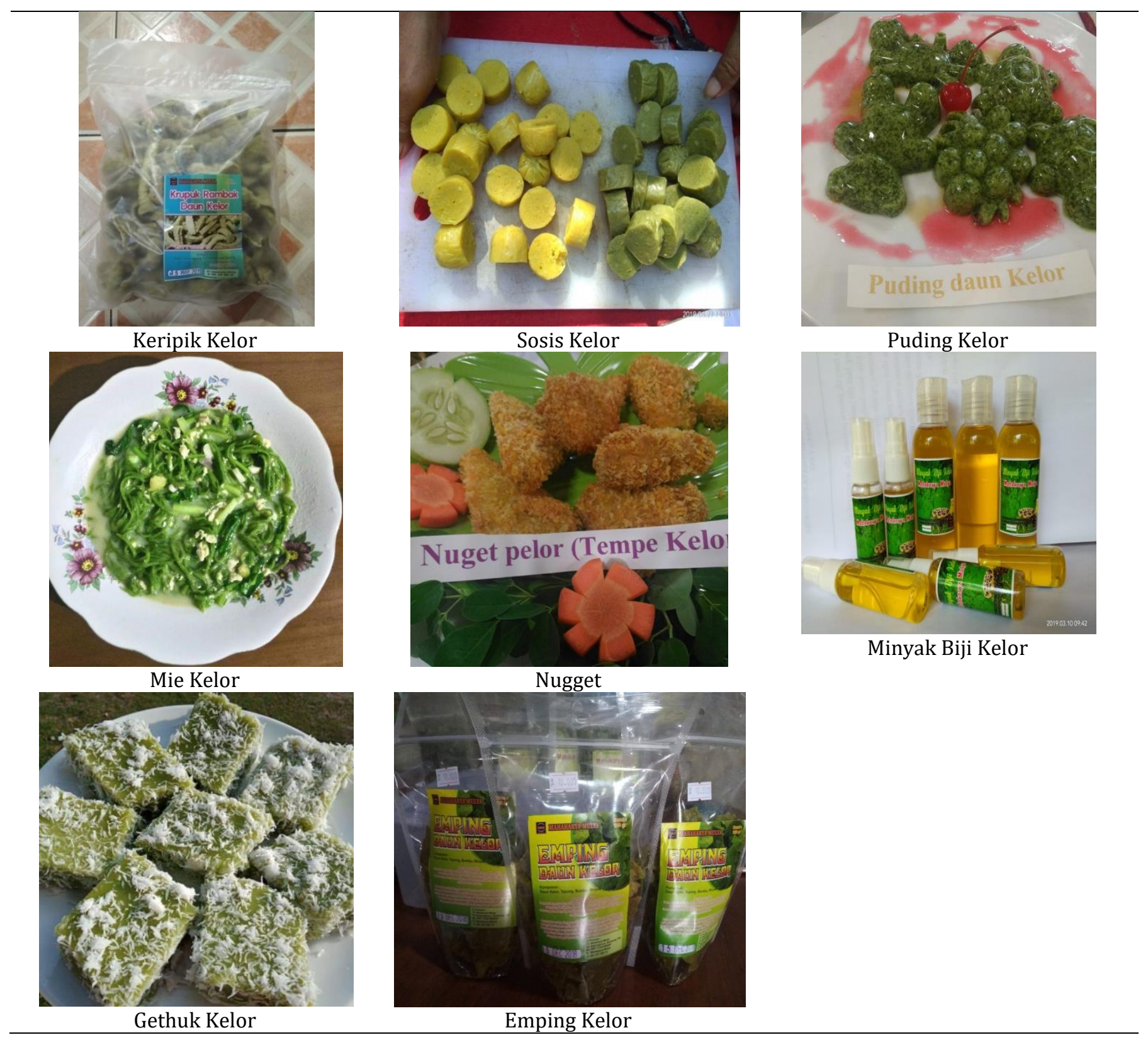

\section{Simpulan}

Terdapat interaksi antara masyarakat desa Kedungbulus Gembong Pati dengan tumbuhan kelor, diantaranya berpotensi sebagai sebagai penghasil pangan seperti sayur bening, ongseng bacem, polong, teh, keripik dll. Sebagi obat tradisional meliputi obat segala penyakit lambung, kolesterol, asam urat, kencing manis, darah tinggi, kanker, kolesterol. Sebagai ritual adat meliputi santet, pengusir roh, penghilang pengasihan, pemandian mayat, dan kesurupan. Selain itu, untuk pembibitan, tanaman pagar untuk pembatas rumah,dan untuk kayu bakar. Pemanfaatan kelor tertinggi adalah untuk pangan. 
Bagian organ tanaman kelor yang paling banyak digunakan oleh masyarakat desa Kedungbulus Gembong Pati yaitu daun, batang, polong. Sumber pengetahuan masyarakat desa Kedungbulus berasal dari nenek moyang (orang tua), rumah produksi "Mahakarya Mulya" dan dukun. Jumlah tanaman kelor tersebar hampir setiap rumah masyarakat Kedungbulus dan dimanfaatkannya secara baik.

Penelitian yang dilakukan baru sebatas satu jenis tumbuhan yang dimanfaatkan oleh masyarakat Kedungbulus karena desa Kedungbulus dijuluki dengan "Kampung Kelor", sedangkan keanekaragaman hayati sangat melimpah, bagi peneliti selanjutnya dapat dikaji secara lebih luas dan mendalam terkait keanekaragaman hayati di desa Kedungbulus atau lebih luasnya di Pati. Penelitian mengenai Etnobotani Tanaman Kelor yang dimanfaatkan masyarakat merupakan penelitian awal dapat dikaji oleh peneliti selanjutnya utamanya ilmu farmasi dan kesehatan sebagai penelitian selanjutnya.

\section{Daftar Pustaka}

Abdiyani, S. 2008. Keanekaragaman Jenis Tumbuhan Bawah Berkhasiat Obat di Dataran Tinggi Dieng Vol. 5. Jakarta : Agromedia Pustaka

Adnyana, M. 2012. Cara Pengobatan Tradisional Baik Dan Benar. Diunduh di http://www.herbaltarupramana.com/artike l-18 tanggal 18 Mei 2019

Aminah, Syarifah. 2015. Kandungan Nut risi dan Sifat Fungsional Tanaman Kelor (Moringa oleifera). Jakarta : Balai Pengkajian Teknologi Pertanian Jakarta

Budhi, Setia. 2015. Kajian Etnobotani Tumbuhan Obat Pada Masyarakat Dusun Semoncol Kecamatan Balai Kabupaten Sanggau. Jurnal Inovasi Kehutanan. Pontianak : Universitas Tanjungpura Pontianak

Ferianita Fahrul, Melati. 2007. Metode Sampling Bioekologi. Yogjakarta : Gajah Mada University Pers
Hidayat, samsyul dkk. 2015. Kitab Tumbuhan Obat. Jakarta : Swadaya grup

Krisnadi, A Dudi. 2015. Kelor Super Nutrisi. Blora : Pusat Informasi dan pengembangan Tanaman Kelor Indonesia

Kurniasih. 2016. Khasiat \& Manfaat Daun Kelor Untuk Penyembuhan Berbagai Penyakit. Yogyakarta: Pustaka Baru Press

Kusuma, Zaky. 2005. Tumbuhan Liar Berkhasiat Obat. Jakarta: Agromedia Pustaka.

Lamk. 2019. Diunduh di http://plantamor.com/species/search tanggal 21 Juni 2019

Latief, Abdul. 2014. Obat Tradisional. Jakarta : Penerbit buku kedokteran EGC

Lismanto. 2016. Diunduh di //www.kedungbulus.com. Diakses tanggal 10 Mei 2019

Louis, Wichita. 2011. Diunduh di htpp://tressforlife.org/our-work/ourintiatives/moringa. tanggal 14 Mei 2019

Mumpuni, K. E.2013. Potensi Pendidikan Keunggulan Lokal Berbasis Karakter dalam Pembelajaran Biologi di Indonesia. Prosiding Seminar Nasional IX Biologi, Sains Lingkungan dan Pembelajarannya dalam Upaya Peningkatan Daya Saing Bangsa. Surakarta: Pendidikan Biologi UNS. Semarang 25 Juli 2017

Suryadarma. 2008. Diktat Kuliah Etnobotani. Universitas Negeri Yogyakarta. Yogyakarta. 